\title{
Analisis Kompetensi Profesional Guru Biologi SMA Negeri Se-Kabupaten Deli Serdang
}

\author{
Hengki Frengki Manullang ${ }^{1}$, Fauziyah Harahap ${ }^{2}$, Ely Djulia ${ }^{2}$ \\ ${ }^{1}$ Guru Biologi di SMA Karya Pembangunan Deli Tua \\ ${ }^{2}$ Program Studi Pendidikan Biologi Pascasarjana, Universitas Negeri Medan, Sumatera Utara, Indonesia
}

\begin{abstract}
The purpose of this study is to look at the professional competenceof Biology teachersof State Senior High School in Deli Serdang based on gender, age, working period, certification and the graduation level. The population in this study were allBiology Teachers of Senior High School in Deli Serdang which had 56 teachers. The sample was purposive sampling with 53 teachers, 318 peer teachers, 3 lecturers as the expert of validators. Descriptive qualitative research was applied.Data were collected by using the test which covered written comprehension test of professionalcompetence. The findings showed that the professional competence of biology teachers were competent based on Permendiknas No. 16 Year 2007.The results of professional competence of teachers was 75 categorized as competent enough which covered written comprehension test, in Grade 10 was 75 categorized as competent, Grade 11 was 75 categorized as competent, and Grade 12 was 74 categorized as competent enough. The professional competence test of the teachers showed that (1) male teachers were more competent rather than female ones, (2) medium age of teachers were more competent rather than young age and old one, (3) 13 up to 24 years working period were more competent rather than 1 up to 12 years as well as 25 up to 36 years, (4) certification of teachers were more competent rather than not certification, (5) Postgraduate graduations were more competence rather than undergraduate ones. This study implicated to be sustainable development for biology teachers of State Senior high school in Deli Serdang.
\end{abstract}

Keywords: Teachers of Biology, Professional Competence, Gender, Age, Working Periods, Certification, Graduate Level

\section{PENDAHULUAN}

Seorang guru harus memiliki sikap profesional agar siswa dapat tumbuh dan berkembang dengan baik. Dengan adanya guru yang profesional dan berkualitas maka akan mampu mencetak anak bangsa yang berkualitas pula. Guru yang profesional dan berkualitas harus memiliki kompetensi yang baik.Kompetensi adalah seperangkat pengetahuan, keterampilan dan perilaku yang harus dimiliki, dihayati, dan dikuasai oleh guru untuk dapat melaksanakan tugas-tugas profesionalanya (Sagala, 2009).

Menurut Balitbang Kemdikbud (2014) keadaan tentang daya serap siswa cakupan materi biologi yang diperoleh dari Balitbang Kemdikbud terlihat adanya 12 kompetensi yang diujikan dalam UN. Dari 12 kompetensi tersebut, 9 kompetensi menunjukkan capaian kompetensi yang selalu menurun, sedangkan 3 kompetensi lainnya mengalami flutuaksi, yaitu kompetensi evolusi, kompetensi peran manusia terhadap lingkungan, dan kompetensi peran makhluk hidup dapat dilihat pada Gambar 1.

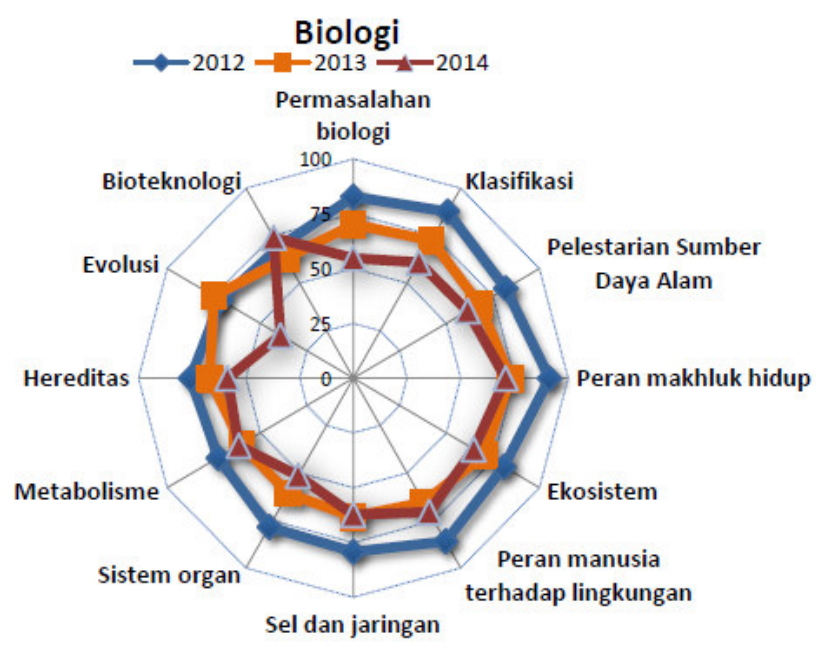

Gambar 1. Daya Serap Siswa Pencapaian Kompetensi Biologi IPA Tahun 2012, 2013, dan 2014 
Selanjutnya adanya capaian kompetensi yang mengalami penurunan cukup drastis dari tahun 2013 ke tahun 2014, sebesar 35.83 (dari $74.96 \%$ ke $39.13 \%$ ) yaitu kompetensi evolusi. Demikian pula dengan kompetensi peran manusia terhadap lingkungan mengalami penurunan sebesar 20.57 (dari $85.93 \%$ ke 65.36\%), dan kompetensi peran makhluk hidup (dari $91.26 \%$ ke $73.19 \%$ ) dapat dilihat pada Tabel 1.

Tabel 1. Daya Serap Biologi IPA Tahun 2012, 2013, dan 2014

\begin{tabular}{lccc}
\hline Kompetensi & $\mathbf{2 0 1 2}$ & $\mathbf{2 0 1 3}$ & $\mathbf{2 0 1 4}$ \\
\hline Permasalahan biologi & 82.89 & 70.24 & 54.77 \\
Klasifikasi & 87.77 & 72.57 & 61.05 \\
Pelestarian Sumber Daya Alam & 81.93 & 67.80 & 61.44 \\
Peran makhluk hidup & 91.26 & 73.19 & 70.91 \\
Ekosistem & 80.86 & 70.12 & 64.71 \\
Peran manusia terhadap lingkungan & 85.93 & 65.36 & 70.47 \\
Sel dan jaringan & 79.13 & 63.09 & 62.19 \\
Sistem organ & 78.28 & 60.70 & 51.36 \\
Metabolisme & 72.56 & 60.09 & 61.51 \\
Hereditas & 75.83 & 66.79 & 58.52 \\
Evolusi & 71.22 & 74.96 & 39.13 \\
Bioteknologi & 69.05 & 63.04 & 74.06 \\
\hline
\end{tabular}

(Sumber: Data Balitbang. Kemdikbud, 2014)

Dari hasil observasi berdasarkan hasil UKG guru biologi SMA Negeri Se-Kabupaten Deli Serdang Tahun 2015 dari 56 guru yang mengikuti UKG, hanya 36\% yang lulus dan guru yang tidak lulus dalam UKG $64 \%$. Nilai rata-rata hasil UKG guru hanya mencapai 48,73. Soal UKG tersebut terdiri dari soal kompetensi pedagogik dan kompetensi profesional.Jika guru memiliki kompetensi yang rendah tentu saja akan berdampak pada kualitas pendidikan siswa. Pada akhirnya akan berdampak pada sumber daya manusia.Berdasarkan fenomena diatas, penulis tertarik untuk mengadakan penelitian terhadap kompetensi guru mata pelajaran biologi berdasarkan perbedaan Gender, usia, lama mengajar, guru sertifikasi, dan tingkat pendidikan guru. Pada penelitian ini, peneliti mengangkat judul penelitian yaitu Analisis Kompetensi Guru Biologi SMA Negeri SeKabupaten Deli Serdang.

\section{METODE PENELITIAN}

Penelitian ini dilaksanakan mulai bulan Desember 2016 sampai dengan Maret 2017. Lokasi penelitian adalah SMA Negeri SeKabupaten Deli Serdang. Populasi yang dijadikan sebagai Subjek dalam penelitian ini adalah seluruh Guru Biologi di SMA Negeri Se-Kabupaten Deli Serdang sebanyak 56 orang yang mengajar di SMA Negeri. Sampel yang digunakan dalam penelitian ini adalah Guru Biologi SMA Negeri Se-Kabupaten Deli Serdang. Sampel yang dijadikan objek penelitian sejumlah 53 orang yang mewakili kelas X, kelas XI, dan kelas XII.

Adapun teknik pengambilan sampel menggunakan teknik total sampling. Desain penelitian dalam penelitian ini adalah penelitian deskriptif dengan menggunakan data kualitatif yang dijelaskan dengan menggunakan kalimat. Adapun prosedur dan tahap-tahap dalam penelitian ini adalah sebagai berikut; (1) Peneliti melakukan survei ke Dinas Pendidikan Kabupaten Deli Serdang untuk memperoleh data jumlah populasi guru biologi SMA Negeri Se-Kabupaten Deli Serdang dan mengambil Data UKG guru biologi SMA Negeri SeKabupaten Deli Serdang. (2) Peneliti menyusun soal tes tertulis pemahaman kompetensi profesional guru untuk mengetahui kompetensi profesional guru dalam bentuk pilihan ganda sebanyak 80 butir soal. (3) Peneliti memvalidasi isi dan konstruk instrumen kepada validator ahli pendidikan, kemudian merevisi instrumen yang dianggap kurang atau tidak valid. (4) Memberikan tes tertulis uji pemahaman kompetensi profesional kepada guru biologi SMA Negeri Se-Kabupaten Deli Serdang secara tertutup pada lembar lampiran 1. (5) Melakukan analisis data guru biologi SMA Negeri SeKabupaten Deli Serdang hasil tes tertulis pemahaman kompetensi profesional, kemudian dikaji kembali berdasarkan perbedaan gender, usia, masa mengajar, sertifikasi, dan tingkat pendidikan guru biologi. (6) Kompetensi profesional menggunakan instrumen berupa tes tertulis pemahaman soal kelas X, kelas XI, kelas XII dan diperoleh skor dalam jumlah soal 
yang terjawab. Setelah penghitungan total skor, kemudian diberikan penilaian yaitu:

(Sugiyono, 2012)
Data yang diperoleh dari semua instrumen yang telah diberikan penilaian dikategorikan dalam bentuk kriteria sesuai dengan pedoman penilaian kinerja guru tahun 2009.

Tabel 2. Penilaian Kriteria Kompetensi Profesional

\begin{tabular}{lcc}
\hline No. & Kriteria & Skor \\
\hline 1 & Sangat Kompeten & $91-100$ \\
2 & Kompeten & $76-90$ \\
3 & Cukup Kompeten & $61-75$ \\
4 & Kurang Kompeten & $0-60$ \\
\hline
\end{tabular}

(Sumber: Pedoman Penilaian Kinerja Guru, 2009)

Setelah data diperoleh dari semua instrumen yang telah diberikan penilaian dan kriteria, maka akan dianalisis dengan menggunakan rumus :

Keterangan:

$$
P=\frac{F}{N} X 100 \%
$$

$$
\begin{aligned}
& \mathrm{P}=\text { Persentase } \\
& \mathrm{F}=\text { Frekuensi } \\
& \mathrm{N}=\text { Jumlah }
\end{aligned}
$$

(Sugiyono, 2012)

Untuk melihat persentase kompetensi guru biologi SMA Negeri Se-Kabupaten Deli
Serdang berdasarkan kriteria; sangat kompeten; kompeten; cukup kompeten; dan kurang kompeten. (7) Membuat kesimpulan dari hasil analisis data yang diperoleh.

\section{HASIL DAN PEMBAHASAN}

\section{Kompetensi Profesional}

Hasil penilaian tes tertulis pemahaman materi kompetensi profesional guru rata-rata 75 kriteria guru cukup kompeten dengan rentang nilai 61-75 cukup kompeten dapat dilihat berdasarkan Gambar 2.

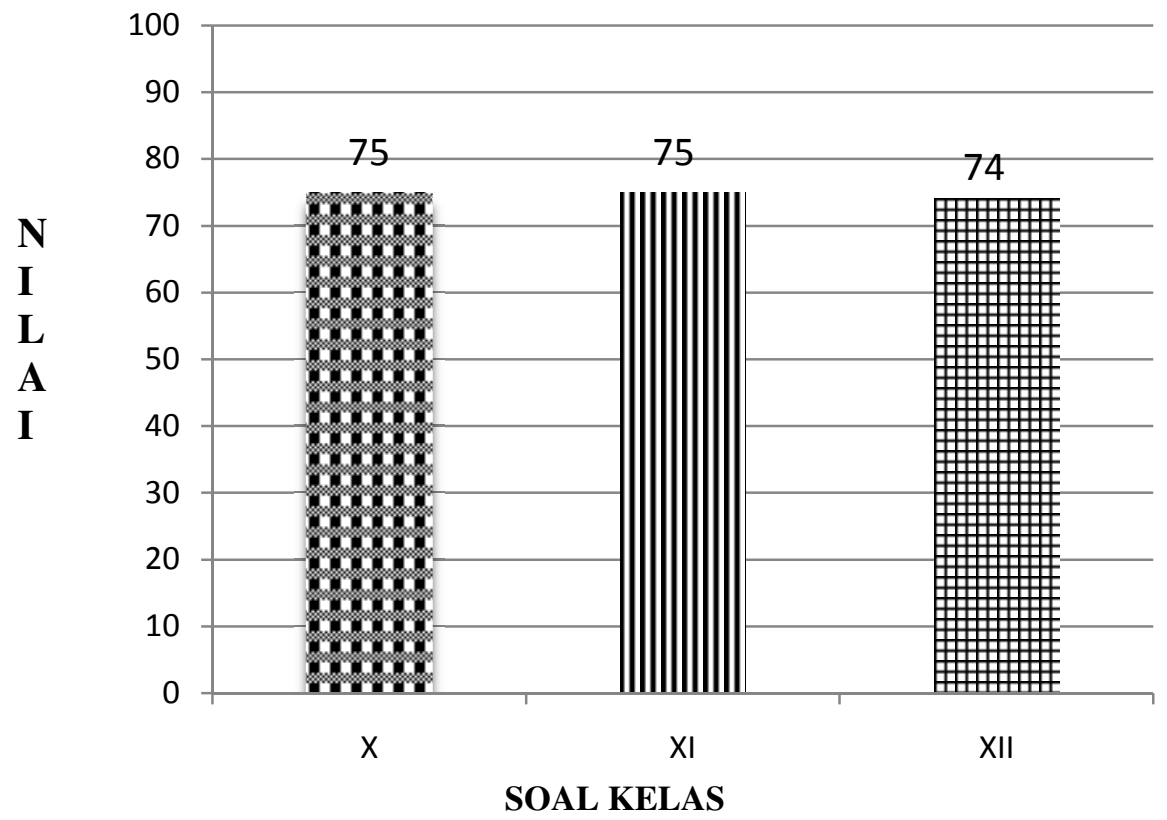

Gambar2. Rata-rataKompetensi Profesional Guru

Berdasarkan gambar di atas menunjukkan bahwa rata-rata penilaian dan kriteria kompetensi profesional guru biologi dalam pemahaman soal tes tertulis kelas X rata-rata 75 kriteria guru cukup kompeten, kelas XI rata-rata
75 kriteria guru cukup kompeten dan kelas XII rata-rata 74 kriteria guru cukup kompeten.

Hasil penelitian ini sudah cukup kompeten menurut Permendiknas No. 16 Tahun 2007 Tentang Standar Kualifikasi Akademik dan Kompetensi Guru bahwa kompetensi 
profesional menguasai materi, struktur, konsep dan pola pikir keilmuan yang mendukung mata pelajaran yang diampu dan menguasai standar kompetensi dan kompetensi dasar mata pelajaran yang diampu. Sehingga hasil uji kompetensi guru (UKG) Tahun 2015 tidak relevan dengan penelitian ini yang menyatakan kompetensi guru biologi SMA Negeri SeKabupaten Deli Serdang Masih rendah 48,73. Hasil penelitian ini sejalan dengan penelitian Hamka et al (2013), mengemukakan nilai ratarata UKG guru biologi di kota Makassar sebesar 46,14; berada pada skala ordinal 3 yang dapat dikategorikan cukup tinggi; sedangkan dari hasil penelitian ini diperoleh kategori kompetensi sangat tinggi sebesar 80,34. Perbedaan hasil UKG online dan uji tes tertulis pemahaman kompetensi profesional guru disebabkan oleh beberapa hal diantaranya: (1) banyak kendala teknis yang dialami oleh guru saat UKG 2012 dilaksanakan secara online; (2) UKG dilaksanakan hampir satu tahun sebelum penelitian dilaksanakan; dan (3) nilai UKG yang kurang memuaskan menjadi motivasi guru biologi untuk mengembangkan kompetensi yang dimiliki. Setelah itu, hasil penelitian kompetensi profesional guru dikaji kembali berdasarkan gender, usia, masa kerja, sertifikasi dan tingkat pendidikan guru biologi SMA Negeri Se-Kabupaten Deli Serdang.

\section{Kompetensi Profesional Berdasarkan Gender \\ Distribusi frekuensi jumlah guru biologi berdasarkan gender disajikan dalam Tabel 3.}

Tabel 3.Distribusi Frekuensi Jumlah Guru berdasarkan Gender

\begin{tabular}{clcc}
\hline No & Gender & Frekuensi & $(\boldsymbol{\%})$ \\
\hline 1. & Laki-laki & 10 & 18,87 \\
2. & Perempuan & 43 & 81,13 \\
\hline & Total & $\mathbf{5 3}$ & $\mathbf{1 0 0}$ \\
\hline
\end{tabular}

Hasil penilaian rata-rata kompetensi profesional guru berdasarkan gender pada Gambar3, menunjukkan guru laki-laki lebih kompetenperolehantotal tes tertulis pemahaman soal 77 kriteria guru kompeten dibandingkan dengan guru perempuan rata-rata 74 kriteria guru cukup kompeten, karena menurut Bratanata (1987) mengatakan perempuan pada umumnya lebih baik pada ingatan dan laki-laki lebih baik dalam berpikir logis. Hasil penelitian ini relevan dengan hasil penelitian Sukarti (2013) mengemukakan bahwa guru laki-laki menghasilkan siswa dengan rata-rata nilai ulangan umum lebih baik dibanding guru perempuan.

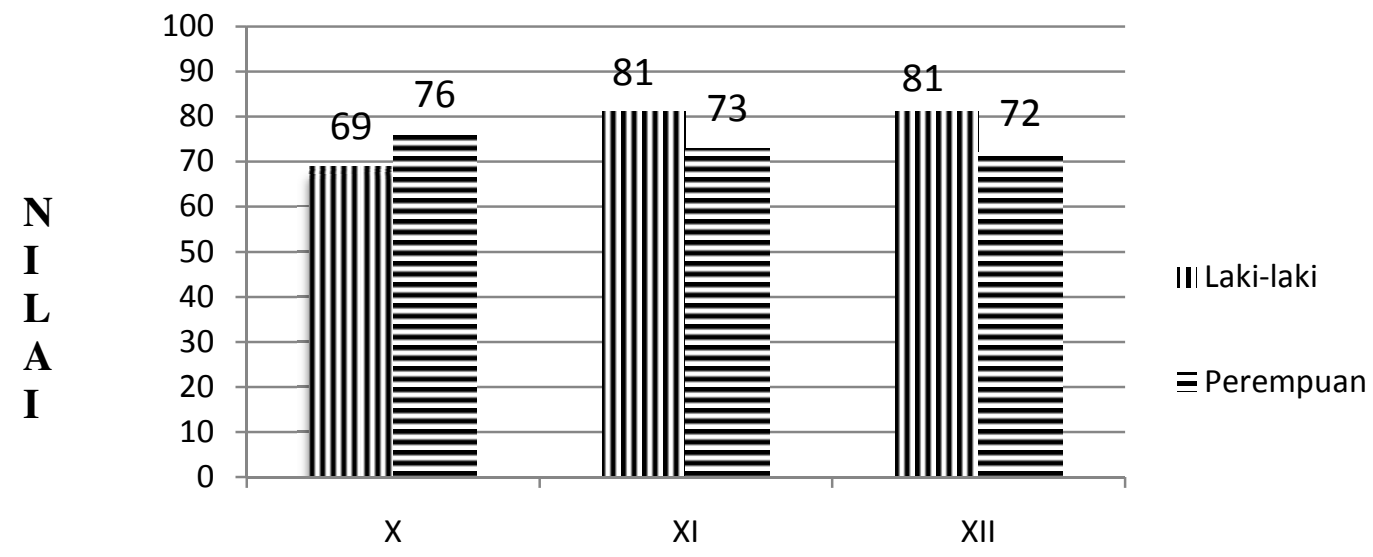

SOAL KELAS

Gambar 3. Rata-rata Kompetensi Profesional Guru Berdasarkan Gender

Berdasarkan hasil persentase rata-rata kompetensi profesional guru laki-laki kriteria; kompeten $70 \%$, cukup kompeten $20 \%$, kurang kompeten $10 \%$, sedangkan persentase rata-rata kompetensi profesional guru perempuan kriteria; kompeten $44 \%$, cukup kompeten $47 \%$, kurang kompeten $9 \%$, dapat dilihat pada Gambar 4. 


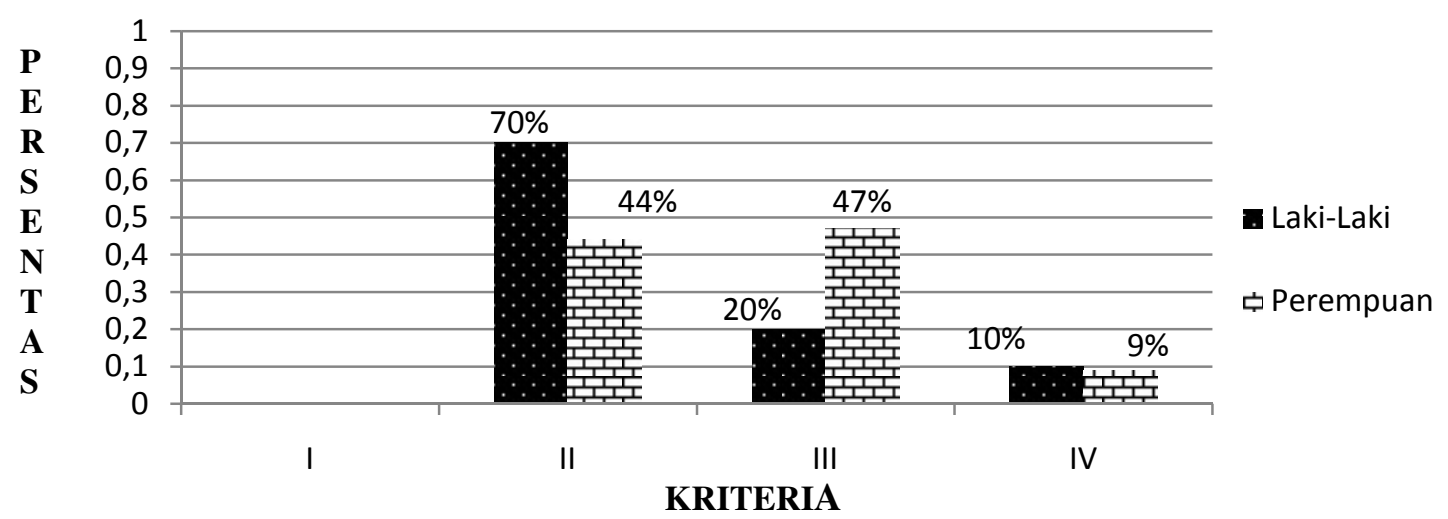

Gambar 4. Rata-rata Persentase Kompetensi Profesinal Guru Berdasarkan Gender Keterangan; I = Sangat Kompeten, II = Kompeten, III = Cukup Kompeten, IV = kurang Kompeten

\section{Kompetensi Profesional berdasarkan Usia}

Distribusi frekuensi jumlah guru biologi berdasarkan usia guru disajikan dalam Tabel 4 .

Tabel 4. Distribusi Frekuensi Guru berdasarkan Usia

\begin{tabular}{clccc}
\hline No & Usia & Rentang Usia (Tahun) & Frekuensi & $(\boldsymbol{\%})$ \\
\hline 1. & Muda & $25-36$ & 2 & 3,77 \\
2. & Sedang & $37-48$ & 26 & 49,06 \\
3. & Tua & $49-59$ & 25 & 47,17 \\
\hline \multicolumn{7}{r}{} & TOTAL & $\mathbf{5 3}$ & $\mathbf{1 0 0}$ \\
\hline
\end{tabular}

Berdasarkan hasil penilaian rata-rata total perolehan soal tes tertulis pemahaman kompetensi profesional guru menunjukkan guru sedang lebih kompeten rata-rata 75 dibandingkan dengan guru usia tua 73 dan guru usia muda 71. Hasil penilaian kriteria kompetensi profesional guru tidak ada perbedaan berdasarkan usia, kriteria guru cukup kompeten dengan rentang nilai 61-75 cukup kompeten.

Menurut Jogiyanto (2007) peningkatan umur berhubungan dengan kesulitan dalam memproses stimulus komplek dan mengalokasikan perhatian kepada informasi di pekerjaan. Hasil penelitian tentang kemampuan dasar guru (Sahertian, 1994), guru memiliki tingkat komitmen. Berdasarkan hasil persentase rata-rata kompetensi profesional guru usia muda kriteria; cukup kompeten 100\%. Persentase rata-rata kompetensi profesional guru usia sedang kriteria; kompeten 58\%, cukup kompeten 34\%, kurang kompeten 8\%.Sedangkan persentase rata-rata kompetensi profesional guru usia tua kriteria; kompeten $44 \%$, cukup kompeten $44 \%$, kurang kompeten $12 \%$, dapat dilihat pada Gambar 5.

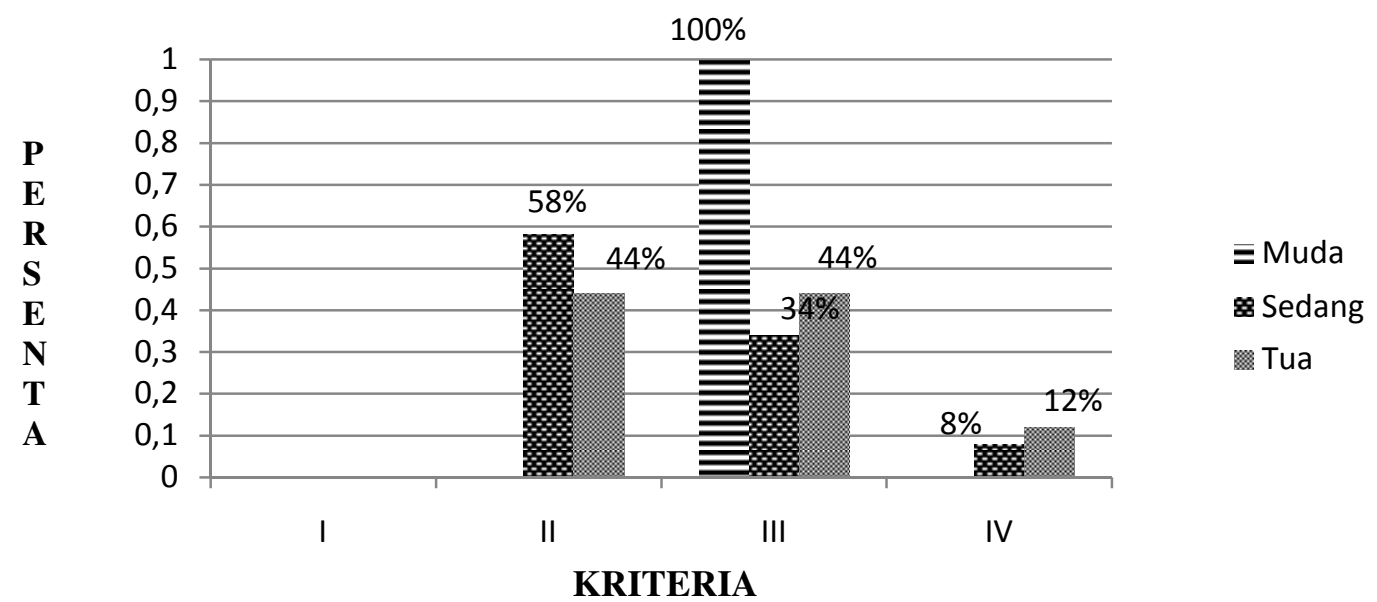

Gambar 5. Rata-rata Persentase Kompetensi Profesional Guru Berdasarkan Usia Keterangan; I = Sangat Kompeten, II = Kompeten, III = Cukup Kompeten, IV = kurang Kompeten 


\section{Kompetensi Profesional Berdasarkan Masa Kerja}

Distribusi frekuensi jumlah guru biologi berdasarkan Masa kerja guru disajikan dalam Tabel 5.

Tabel 5. Distribusi Frekuensi Guru berdasarkan Masa Kerja

\begin{tabular}{ccccc}
\hline No & Masa Kerja (Tahun) & Rentang Masa Kerja & Frekuensi & $(\boldsymbol{\%})$ \\
\hline 1. & $1-12$ & $1-12$ & 10 & 18,87 \\
2. & $13-24$ & $13-24$ & 27 & 50,94 \\
3. & $25-36$ & $25-36$ & 16 & 30,19 \\
\hline \multicolumn{2}{r}{ TOTAL } & $\mathbf{5 3}$ & $\mathbf{1 0 0}$ \\
\hline
\end{tabular}

Berdasarkan hasil penilaian dan kriteria rata-rata kompetensi profesional guru menunjukkan guru masa kerja 13-24 tahun lebih kompeten rata-rata 80 kriteria guru kompeten dibandingkan kompetensi profesional guru masakerja 25-36 tahun rata-rata 74 kriteria guru cukup kompeten dan guru masakerja1-12 tahun rata-rata 73 kriteria guru cukup kompeten, dapat dilihat pada Gambar 6.Hasilinirelevandengan Bloom et al(1981) mengemukakan masa kerja guru merupakan karakteristik guru yang patut dipertimbangkan dalam menunjang pencapaian kualitas penampilanya dalam mengajar.

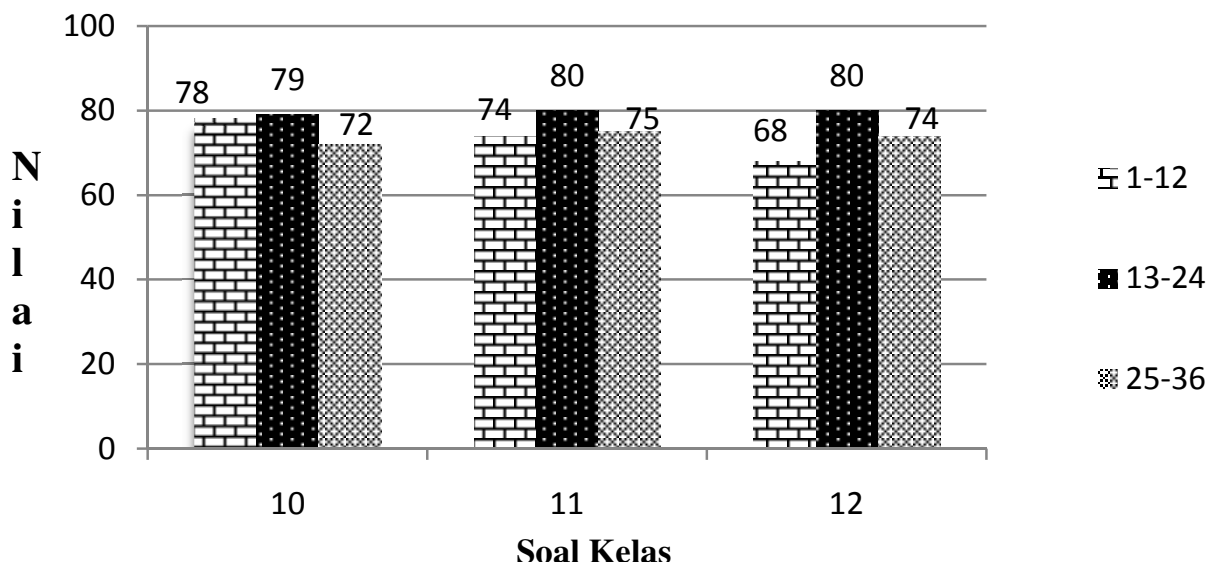

Gambar 6. Rata-rata Kompetensi Profesional Guru Berdasarkan Masa Kerja

Berdasarkan hasil persentase rata-rata kompetensi profesional guru masa kerja 1-12 tahun kriteria; kompeten $40 \%$, cukup kompeten $50 \%$, kurang kompeten $10 \%$. Guru masa kerja 13-24 tahun kriteria; kompeten 59\%, cukup kompeten 37\%, kurang kompeten $4 \%$. Sedangkan guru masa kerja 25-36 kriteria; kompeten $37 \%$, cukup kompeten $44 \%$, kurang kompeten 19\%, dapat dilihat pada Gambar 7.

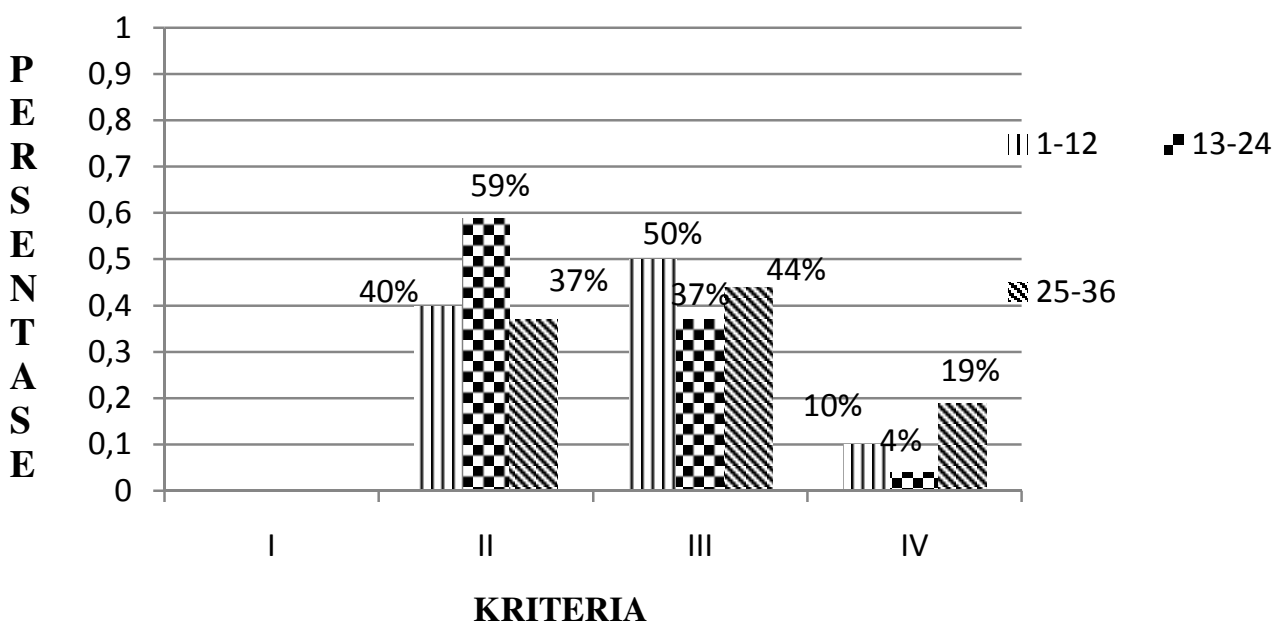

Gambar 7. Rata-rata Persentase Kompetensi Profesional Guru Berdasarkan Masa Kerja Keterangan; I = Sangat Kompeten, II = Kompeten, III = Cukup Kompeten, IV = kurang Kompeten 


\section{Kompetensi Profesional berdasarkan Sertifikasi}

Distribusi frekuensi jumlah guru biologi berdasarkan sertifikasi disajikan dalam Tabel 6 .

Tabel 6. Distribusi Frekuensi Guru berdasarkan Sertifikasi

\begin{tabular}{llcc}
\hline No & Sertifikasi & Frekuensi & $(\boldsymbol{\%})$ \\
\hline 1. & Sudah & 52 & 98,11 \\
2. & Belum & 1 & 1,89 \\
\hline & Total & $\mathbf{5 3}$ & $\mathbf{1 0 0}$ \\
\hline
\end{tabular}

Hasil penilaian dan kriteria rata-rata kompetensi profesional guru yang sudah sertifikasi rata-rata 75 kriteria guru kompeten lebih kompeten dibandingkan dengan guru yang belum sertifikasi rata-rata 73 kriteria guru cukup kompeten, dapat dilihat pada Gambar 8. Hasil ini relevan dengan penelitian Suarmandan Syahza (2012) dampak kebijakan sertifikasi terhadap kinerja guru di daerah riau, terjadi perbedaan kinerja antara guru yang sudah tersertifikasi dengan guru yang belum tersertifikasi. Thabrani (2015) juga mengemukakan terdapat perbedaan yang signifikan bagi guru yang sudah sertifikasi dan guru yang belum mengikuti sertifikasi. Guru sudah sertifikasi lebih baik dalam penguasaan materi, proses pembelajaran, hubungan interpersonal dan penilaian berbasis kelas.

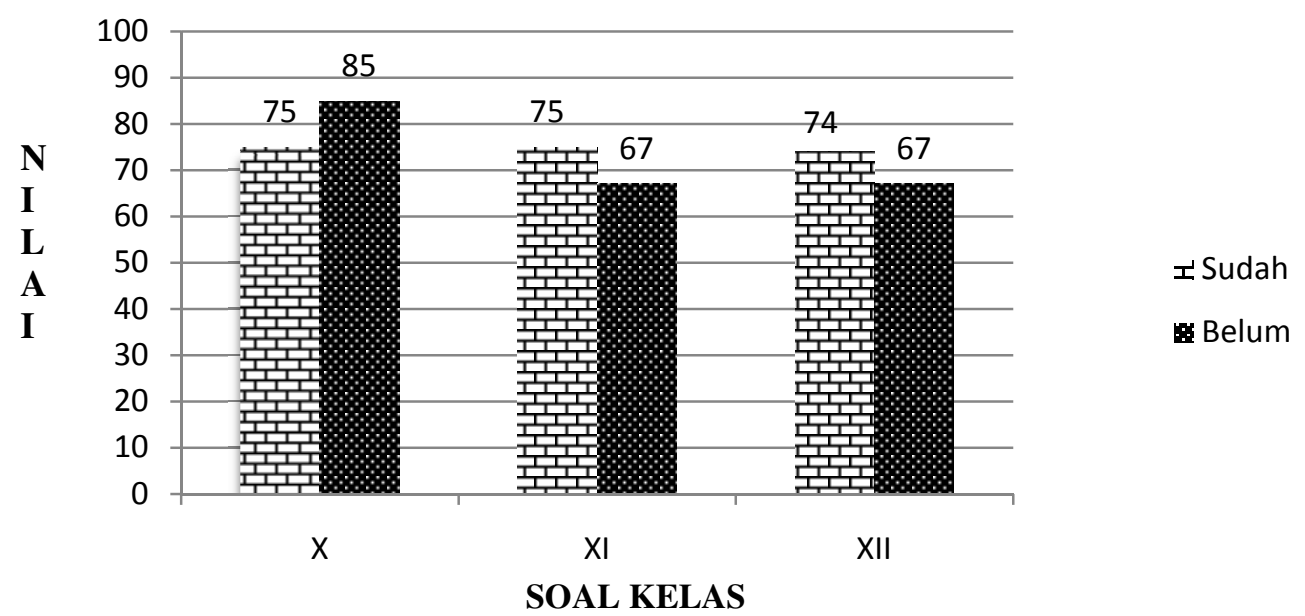

Gambar 8. Rata-rata Kompetensi Profesional Guru Berdasarkan Sertifikasi

Berdasarkan hasil persentase rata-rata kompetensi profesional guru sudah sertifikasi kriteria; kompeten 50\%, cukup kompeten $40 \%$, kurang kompeten $10 \%$. Persentase rata-rata kompetensi profesional guru belum sertifikasi kriteria; kompeten $100 \%$, dapat dilihat Gambar 9.

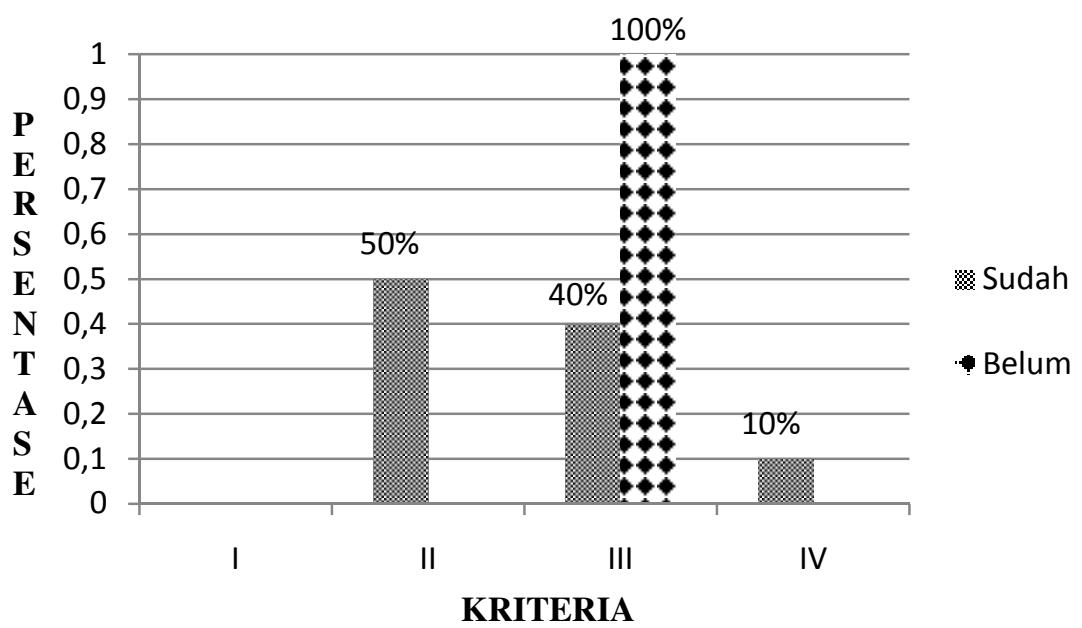

Gambar 9. Rata-rata Persentase Kompetensi Profesional Guru Berdasarkan Sertifikasi Keterangan; I = Sangat Kompeten, II = Kompeten, III = Cukup Kompeten, IV = kurang Kompeten 


\section{Kompetensi Profesional berdasarkan Tingkat Pendidikan}

Distribusi frekuensi jumlah guru biologi berdasarkan tingkat pendidikan disajikan dalam Tabel 7.

Tabel 7. Distribusi Frekuensi Guru Berdasarkan Tingkat Pendidikan

\begin{tabular}{lccc}
\hline No & Tingkat Pendidikan & Frekuensi & $(\boldsymbol{\%})$ \\
\hline 1. & S1 & 37 & 69,81 \\
2. & S2 & 16 & 30,19 \\
\hline & Total & $\mathbf{5 3}$ & $\mathbf{1 0 0}$ \\
\hline
\end{tabular}

Hasil penilaian dan kriteria rata-rata kompetensi profesional guru tingkat pendidikan S2 rata-rata 78 kriteria guru kompeten, lebihkompetendibandingkandengan guru tingkatpendidikan S1 rata-rata 75 kriteria cukup kompeten, dapat dilihat Gambar 10.Sejalan dengan teori Hamalik (2003) tingkat pendidikan guru adalah jenjang yang ditempuh guru untuk menunjukkan pada perbedaan tingkat keilmuannya. Hasil penelitian ini relevan juga dengan penelitian Nurwahidah (2014) mengemukakan bahwa terdapat perbedaan yang positif dan signifikan penguasaan kompetensi profesional antara guru berlatar pendidikan sarjana (S1) dengan magister (S2) di SMA Negeri 11 Makassar. Kompetensi profesional magister (S2) di SMA Negeri 11 Makassar lebih baik dibandingkan dengan kompetensi profesionalguru berlatar pendidikan sarjana (S1).

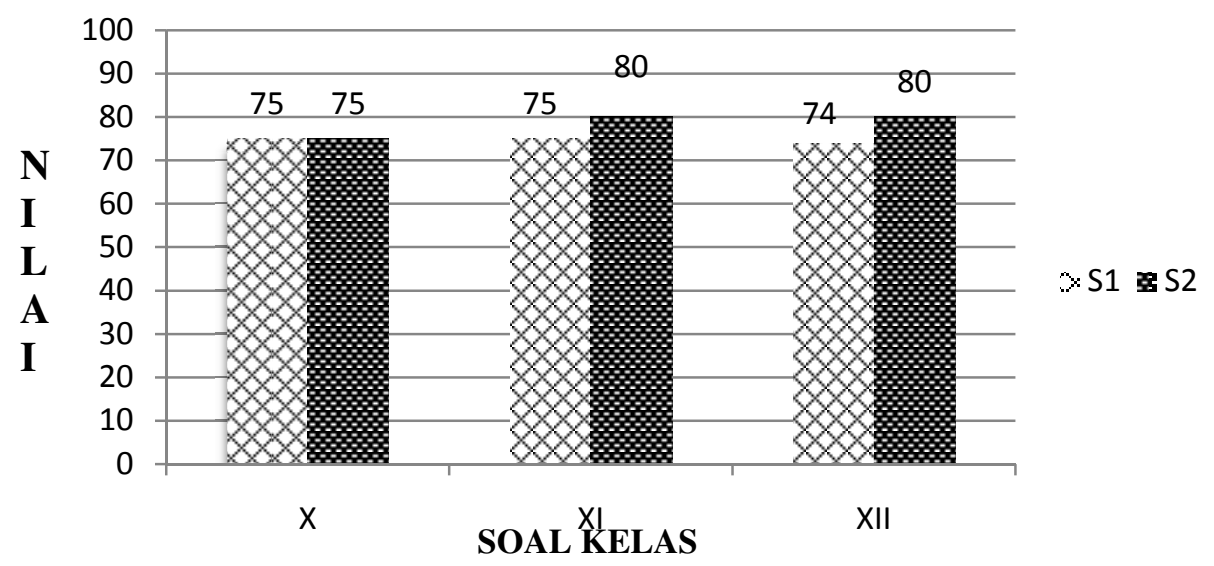

Gambar 10. Rata-rata Kompetensi Profesional Guru Berdasarkan Tingkat Pendidikan

Berdasarkan hasil persentase rata-rata kompetensi profesional guru tingkat pendidikan S1 kriteria; kompeten 35\%, cukup kompeten $54 \%$, kurang kompeten $11 \%$. Persentase rata- rata kompetensi profesional guru pendidikan S2 kriteria; sangat kompeten 6\%, kompeten $81 \%$, cukup kompeten 13\%, dapat dilihat pada Gambar 11.

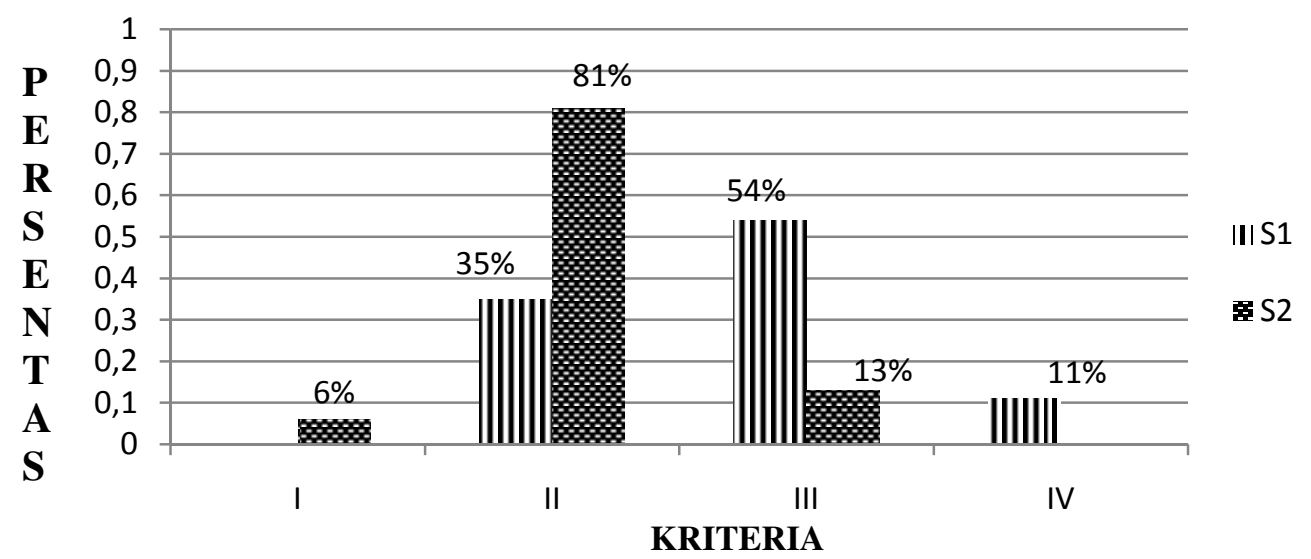

Gambar 11. Rata-rata Persentase Kompetensi Profesional Guru Berdasarkan Tingkat Pendidikan Keterangan; I = Sangat Kompeten, II = Kompeten, III = Cukup Kompeten, IV = kurang Kompeten 
Adapun kesimpulan dalam penelitian ini adalah Kompetensi profesional guru biologi SMA Negeri Se-Kabupaten Deli Serdang nilai rata-rata 75 kriteria guru cukup kompeten sudah sesuai dengan ketentuan-ketentuan yang tercantum dalam Permendiknas No 16 Tahun 2007. Hasil kajian kompetensi profesional guru biologi SMA Negeri Se-Kabupaten Deli Serdang berdasarkan; (1) gender; guru laki-laki lebih kompeten dibandingkan dengan guru perempuan, (2) usia; guru usia sedang lebih kompeten dibandingkan dengan guru usia muda dan guru usia tua, (3) masa kerja; guru masa kerja 13-24 tahun lebih kompeten dibandingkan dengan guru masa kerja 1-12 tahun dan 25-36 tahun, (4) sertifikasi; guru yang sudah sertifikasi lebih kompeten dbandingkan dengan guru yang belum sertifikasi, (5) tingkat pendidikan; guru tingkat pendidikan S2 lebih kompeten dibandingkan dengan guru tingkat pendidikan S1.

\section{DAFTAR PUSTAKA}

Bratanata, S. 1987. Pengertian-pengertian Dasar dalam Pendidikan Luar Biasa. Jakarta: Depdikbud.

Bloom, Madaus, Hasting. 1981. Methods Grading in Summative Evaluation. New York: McGrawHill.

Balitbang Kemdikbud. 2014. Laporan Hasil Ujian Nasional. Jakarta: ISBN.

Hamalik. 2003. Proses Belajar Mengajar.Jakarta: PT. Bumi Aksara.

Hamka, L., Andi, A.Azis, Muhiddin, P. Rachmayani, A. 2013. Analisis Kompetensi Profesional Guru Biologi SMA Negeri di Kota Makassar. Jurnal Bionature. Vol.14 No.1.

Nurwahidah.2014. Studi Komparasi Penguasaan Kompetensi Profesional Antara Guru Berlatar Pendidikan Sarjana (S1) Dengan Magister (S2) di SMA Negeri 11 Makassar. Jurnal Sosialisasi Pendidikan Sosiologi-FIS. Universitas Negeri Makassar.

Jogiyanto, H. 2007. Sistem Informasi Keperilakuan. Edisi Pertama. Yogyakarta: Penerbit Andi Offset.

Permendiknas No. 16 Tahun 2007. Tentang Standar Kualifikasi Akademik dan Kompetensi Guru. Jakarta.

Peraturan Menteri Negara Pendayagunaan Aparatur Negara Dan Reformasi Birokrasi No. 16 Tahun 2009. Tentang Jabatan Fungsional Guru dan Angka Kreditnya. Jakarta.

Sagala, S., 2009. Kemampuan Profesional Guru dan Tenaga Kependidikan. Bandung: Alfabeta.

Sukarti. 2013. Isu Gender Dan Sertifikasi Guru. Universitas Terbuka. Purwokerto. Jurnal Pendidikan, Volume 14, Nomor 1, Maret 2013, 38-43
Sugiyono. 2012. Metode Penelitian Pendidikan Pendekatan Kuantitatif. Bandung: Alfabeta.

Sahertian. 1994. Profil pendidikan Profesional Yogyakarta: Andi Offset.

Suarman dan Syahza. 2012. Dampak Kebijakan Sertifikasi Terhadap Kinerja Guru Di Daerah Riau, Lembaga Penelitian Universitas Riau, Pekanbaru. Jurnal Pendidikan.

Thabrani, M. 2015. Komparasi Guru yang Telah Mengikuti Sertifikasi dan yang Belum Mengikuti Sertifikasi Terhadap Kompetensi Profesional di Madrasah Aliyah Pondok Pesantren Jember. Institut Agama Islam Negeri. Jurnal Fenomena. Vol. 14 No. 1. 